\title{
Irish medical student culture and the performance of masculinity, $c .1880-1930$
}

Medical education, for the male students who undertook it in the nineteenth and twentieth centuries, marked an important transition from boyhood to manhood, regardless of location. Varying aspects of medical studies were described as 'rites of passage' or hardships, competitive feats that students had to get through to in order to complete their metamorphosis from medical student to fully-fledged member of the profession. These rites of passage were couched in increasingly masculine terms and students' spaces became centres for the performance of masculinity. However, such rites of passage and the ways they were configured as masculine activities, have received limited attention from historians. ${ }^{1}$ In his ambitious comparative study of medical education in Britain, France, the United States and Germany, Thomas Neville Bonner asserted that 'the lives and experiences of students in general and their impact on medical education have been too little studied'. ${ }^{2}$ Similarly, Keir Waddington has pointed out that studies of medical students have tended to focus on the structure of medical training as part of the history of professionalization and more recently attention has been directed at the move away from book learning and apprenticeship to the institutionalization of teaching in the eighteenth century and the impact of Paris medicine'. 3 Recent research has honed in on the social backgrounds and day-to-day experiences of medical students. ${ }^{4}$ Crowther and Dupree, for example, in their comprehensive study of the social backgrounds and careers of medical students at Glasgow and Edinburgh in the nineteenth century, have illuminated aspects of medical student life such as living conditions and extra-curricular activities. Furthermore, they have shown how friendships formed in medical school could prove useful assets in graduates' careers. ${ }^{5}$

Other recent studies of the history of medical education have tended to focus on the educational experiences of medical students, while some have highlighted how the image of the medical student was improved in the nineteenth century and the importance of shared educational activities in helping to create cohesive bonds between future medical practitioners. ${ }^{6}$ However, although historians of education have illuminated how manliness became a crucial force in student life in the nineteenth and twentieth century, particularly in the context of British universities, less attention has been paid to how masculine ideals were passed on to medical students and how educational and extra-curricular spheres became centres of gendered performances and sites for the maintenance of hegemonic masculinity. ${ }^{7}$ There has also been a historiographical gap in research on the history of Irish medical 
education. Institutional histories of Irish medical schools have tended to focus on the foundation of these schools and the professors involved with limited, if any, discussion of medical students' experiences. ${ }^{8}$ This article attempts to bridge both of these gaps and examine the history of medical student culture in Ireland through a gendered lens. In doing so, I also hope to contribute to understandings of medical student image and identity. ${ }^{9}$

I will illustrate how rites of passage in medical education became imbued with masculine tropes. Ireland makes an interesting case study of masculinity in medical student culture because of the fact that women were accepted to Irish medical schools earlier than many of their British counterparts and appear to have had been integrated with regard to their educational experiences. ${ }^{10}$ In spite of this, the transformation of student to practitioner was often symbolised as the transformation of boy to man. Ultimately, as I will argue here, identity construction, through various rites of passage and social activities aimed to preserve Irish medicine as a masculine domain. Women students, though largely treated in an inclusive manner for educational experiences, were generally excluded from these activities. ${ }^{11}$ As Dyhouse has shown for British medical schools, 'women might be just about tolerable if they confined themselves to the role of spectators, when (whether in the operating theatre or in the sports field) their role was essentially one of admiring male performance. ${ }^{12}$

The article will focus on the performance of masculinity in the six Irish medical schools in existence in the late nineteenth and early twentieth century: these being the three Queen's Colleges in Cork, Galway and Belfast, and Trinity College, the Royal College of Surgeons and the Catholic University (later University College Dublin), in Dublin. Students could undertake their clinical practice at a range of hospitals, the majority centring on Dublin. Although each of these medical schools had their own distinctive religious climates and students' educational experiences varied from one to another, it is evident that a general medical student culture emerged with elements common to each of the institutions. Arguably, medical student culture in Ireland carried many of the same hallmarks as British medical student culture in this period. In both contexts, students' education was regulated by the General Medical Council, although Irish students had more freedom with regard to choice of hospitals for their clinical experience.

I focus here on the period of the late 1880 s to the 1930 s when women students started to become a noticeable presence in Irish medical schools. As will be shown, attitudes and behaviour appear to have been consistent throughout this period. This period witnessed an 
intensely overcrowded Irish medical marketplace with emigration being a common part of medical graduate life. ${ }^{13}$ More generally, in Irish society, this period was witness to the rise of nationalism. A particular concept of Irish 'manliness' influenced by nationalism began to emerge. ${ }^{14}$ The early twentieth century was politically and socially turbulent up until and following the foundation of the Irish Free State which came into being in 1922. Furthermore, it was one of important social and political change internationally during which the First World War deepened certain aspects of masculinity such as the urge to serve in a cause higher than the individual and 'tied nationalism and masculinity together more closely than ever before'. ${ }^{15}$

Raewyn Connell's concept of hegemonic masculinity provides a useful framework for examining the history of medical student culture in Ireland. Hegemonic masculinity may be defined as 'the configuration of gender practice which embodies the currently accepted answer to the problem of the legitimacy of patriarchy, which guarantees (or is taken to guarantee) the dominant position of men and the subordination of women'. ${ }^{16}$ Hegemonic masculinity is always created in relation to various subordinated masculinities and women, allowing for 'the maintenance of practices that institutionalise men's dominance over women'. ${ }^{17}$ The article will focus on masculine displays in various spheres of Irish medical schools. As John Tosh has shown, the public demonstration of masculinity occurs in three key areas: home, work and all-male associations, with the appeal of all-male conviviality being felt the most among young unmarried men "who are temporarily denied the full privileges of masculinity'. ${ }^{18}$ Medical students certainly fit into this category, occupying largely homosocial spaces. All-male settings 'sustained gender privilege, while at the same time imposing a discipline on individuals in the interests of patriarchal stability'. ${ }^{19}$ As sociologist Sharon R. Bird has surmised, homosociality helps to perpetuate hegemonic masculinity in three main ways: emotional detachment, competitiveness, and sexual objectification of women. ${ }^{20}$ All three of these aspects can be applied when exploring medical student activities in the late nineteenth and early twentieth century from a gendered perspective.

The primary source for this article is the contemporary Irish student press. Deslandes has argued, that for Oxbridge, although the student press was produced by a minority of the student population, its 'broad dissemination among students, as well as its timeliness, render it far superior to the memoirs, reflections and autobiographies usually consulted' ${ }^{21}$ The same may be applied to the Irish context. Irish student magazines I will draw on include Q.C.C., 
The Quarryman (Cork), Q.C.B. (Belfast), Q.C.G. (Galway), Mistura, the R.C.S.I. Students' Quarterly (Royal College of Surgeons), The National Student, St. Stephen's (Catholic University, later U.C.D.), and T.C.D.: A College miscellany (Trinity College Dublin), most of which began to be produced from the early 1900s. These magazines were produced for and by students and usually contained news from the different faculties, cartoons, stories and poems and provide an insight into the experiences of students in the period. I will also utilise the memoirs of Irish doctors, novels about medical student life and the records of student societies and sports clubs. Notably, as will become apparent, the voices of women medical students were often silent in these sources, and when women students are mentioned, they were characterised in a particular way. Moreover, the ways in which students wrote about their experiences, either at the time of their study, or afterwards, in their memoirs, reveals the role of collective memory in fashioning a particular image and identity of the medical student which potentially served to alienate female practitioners.

Masculine displays and the cultivation of the image of the medical student as a rowdy, boisterous, and predominantly male individual became an important force in segregating men and women students. Manliness was a crucial force running through the initiation and often ritualistic rites of passage that made up the five to six years of medical study at Irish universities. Heather Ellis has shown how the University of Oxford in the first half of the nineteenth century perceived its role to be 'that of turning boys to men', with manliness being seen as an ideal and 'defined by the possession of maturity, both moral and intellectual, and constructed primarily in opposition to notions of boyishness, rather than overtly gendered ideas of femininity or effeminacy'.22 Although Irish universities represent a different social and cultural context to the elite universities of Oxford and Cambridge, manliness was often represented as the transition from boyhood and this is what I will take manliness to represent for the purposes of this article. ${ }^{23}$ The spaces I will focus on here include the lecture theatre, dissecting room and the sports field. Dissection was viewed as an important rite of passage for students in garnering emotional detachment, while the lecture theatre, though regimented, was a common site of student pranks and boisterous behaviour. Finally, the sports field was important in helping to create a well-rounded medical student, cultivating ideals such as strength of nerve and fostering competition.

\section{The transformation of the 'gyb': rites of passage in the educational sphere}


First-year medical students, often referred to as 'gybs', were characterised in the Irish student press as being jovial in nature, 'youths with strange and weird notions of student life', 'outspoken and boisterous', 'young hooligans' before they settled down into hard work as the years progressed. ${ }^{24}$ They were also commonly referred to as 'boys', with one piece in 1911, describing their 'school-boy shyness'. ${ }^{25}$ Other pieces remarked on the 'appearance of stupidity and awkwardness' which marked the first stage of the development of 'the medicus'. ${ }^{26}$ Articles in the Irish student press by more senior medical students often disapprovingly remarked on the boisterous behaviour of the younger students. A piece in 1903, for instance, encouraged the first-year student to cultivate 'a less bumptious demeanour that at present characterises him. Of course, he is young and will settle down in time but a speedy recognition of his exact importance in the College will conduce both to his own future comfort and that of his seniors'. ${ }^{27}$ In this sense, first-year or pre-clinical students were characterised as 'boys' before undertaking a transformation as a result of their clinical experiences.

Members of the Irish medical profession frequently wrote about this transformative process. Rawdon Macnamara, a professor at the Royal College of Surgeons, and surgeon to the Meath Hospital, in an introductory address to students at the Meath Hospital in 1884, remarked how students came to the wards 'rough, selfish, thoughtless, unsympathetic', however, 'after a very short time, let occasion arise, who so gentle, who so thoughtful, who so sympathetic, who so self-denying, who so tender-hearted? What a wonderful transformation! ${ }^{28}$ After this transformation had taken place, the medical practitioner had an important, heroic role to play in society, binding and healing 'not merely the limbs of their patients, but the more formidable fractures which separate class from class' ${ }^{29}$ Similarly, a student writing in 1912 shared this perspective, outlining how the early years of medical study were filled with pranks before a transformation which produced a more subdued and serious graduate: 'But we are all changed since then. Medicine to her students is not always a goddess fair; sometimes she seems a vampire sucking the life of her victims, draining from them every particle of every form of vitality except what is needed for her work' ${ }^{30}$ For this student, the jovial aspects of the earlier years of study were soon replaced by hard work, resulting in a more serious graduate at the end of the degree. Students also described the transformation in similar ways, using terms such as 'chrysalis', 'pupa' or 'embryo' to describe the medical student prior to conversion into a qualified practitioner. ${ }^{31}$ 
In order to undertake this transformation from student into doctor, medical students took part in a range of masculine rites of passage and initiation which took place in a variety of spheres. Arrival at a university first involved matriculation or a meeting with the university registrar. One student at the Catholic University Medical School in 1905, wrote of his first day when he presented himself in the draughty hall and 'allowed myself to be patronised by some of the men, all the time essaying to show an acquaintance with the place which I was far from feeling. My first awakening was rude and sudden, occasioning much laughter to such of the men as were congregated in the porch at the time, and leaving your humble servant utterly crushed and abashed'. ${ }^{32}$ For many Irish medical students, this transformation involved not just conversion from boy to man but also involved becoming more civilised as a result of integration into city life, with student magazines regularly referring to students 'coming up to Dublin' from the country.

Hardship was also an important element in cultivating a manly identity among medical students. Sir Thomas Myles (1857-1937), an Irish surgeon, speaking at a meeting of the Belfast Medical Students' Association (later BMSA) in 1912 remarked that 'the medical student must always remain apart from the genial mass of mankind. Death and suffering were always with him. What were tragedies to others were commonplace to him' ${ }^{33}$ Experiences at medical school were cloaked in language of hardship and suffering - the idea that students had to overcome difficulty and adversity before they could become mature into medical practitioners.

The most important educational rite of passage for medical students, regardless of location, was undoubtedly the first entrance to the dissecting room. ${ }^{34}$ This was usually produced feelings of fear and trepidation. ${ }^{35}$ Irish medical students regularly reported needing preserves of courage and their feelings of anxiety. Others commented on the telling of ghoulish stories by other students prior to students entering the dissecting room. One Dublin student writing in 1911 described the student's first entrance to the dissecting room in the following way:

Acting under competent advice he robes himself in faultlessly ironed apron and sleeves of a dangerous and steely brightness, and finally, with a Birmingham [anatomical note book by Ambrose Birmingham] clasped tightly 'neath his axilla, makes his entrée to a place, which, for two years, will be, or should be, his almost constant habitation'. ${ }^{36}$ 
Following his first day in the dissecting room, notably aided by a female student who helped him with his task, 'he trots off dutifully to the digs - a new man. He is no longer the one who feared to enter the dissecting room, he is now a medical, his step is more assured, and his Birmingham more prominent than is really compatible with his year'. ${ }^{37}$

The physical appearance of medical students also underwent transformation and each stage of the student's maturation was characterised by an item of clothing. Initially, according to one Irish student's account, the medical student wore a clean, 'faultlessly ironed' apron in the dissecting room, sold to him by 'the fatherly porter' ${ }^{38}$ This became covered in dirt and blood after his initiation in the dissecting room. Upon entering third year of their studies, entering the hospital and the next stage of their development, 'scalpel, forceps and greasy dissecting coats have been discarded; likewise the catcalls and boisterousness of other days. Our social standing and a new hat weighs heavily upon us - lovely men to be sure'. ${ }^{39}$ Similarly, a poem published in 1917 remarked that after a month or two after the first entrance to the dissecting room, there had been a change 'since his initiation', and that student's 'new white dress has now been sloped in many a mess; he thinks it recreation! ${ }^{40}$ Male medical students were often marked out by their dirty aprons. In 1917, the Royal College of Surgeons requested that students ensure that their dissecting coats were always clean and white. One student commented that he, like the majority of his counterparts, with the exception of the ladies, had made his coat last all term without washing it. ${ }^{41}$

Smoking was an important element of the dissecting room experience and served to reinforce notions of masculinity while also helping to ease the nerves that went along with the practice of dissection. ${ }^{42}$ Indeed, as Nye has argued, for members of the medical profession more generally, smoking was part of 'the unholy trinity of smoking, drinking and profanity' which 'were salient expressions of male exclusivity if not aggression'. ${ }^{43}$ Recognising the popularity of smoking among their students, many of the Irish medical schools provided smoking-rooms for students from the $1880 \mathrm{~s}$. ${ }^{44}$ Smoking while dissecting was a common practice among the male students and was permitted by university professors. Medical students at Trinity College Dublin in 1900, for example, were presented in the following way:

the groups of youthful anatomists discussing football, politics \&c, while they cut and chop - the eager student, heedless of all around, with his pipe hanging listlessly between his teeth as he vigorously plies scalpel and forceps, and last, but surely not least, the far-famed "stove class". 45 
J. Johnston Abraham recalled students in the dissecting room at Trinity College in the 1890s working 'away steadily, smoking as we did so', and even by the $1950 \mathrm{~s}$, this practice still appears to have been commonplace. ${ }^{46}$ Thomas Hennessy, who studied at University College Dublin in the 1950s, referred in his autobiography to the anatomy professor permitting students to smoke in the dissecting room 'because some people found the smell of formaldehyde a little difficult to take'. ${ }^{47}$ Hilton's research on smoking in popular culture in Britain has shown through his study of Mass Observation questionnaires, that 'the cigarette became important in public displays of masculinity' and that the 'proffering of cigarettes to friends and colleagues helped define the group', helping to cultivate a group identity through which masculinities could be defined. ${ }^{48}$ Illustrating this point, a law student who visited the dissecting room in Trinity in 1927 felt isolated from the medical students' group dynamic because 'Everyone was smoking and I had no cigarettes; I didn't like to ask for one because I know a medical student is always smoking his "last one" and I didn't care to embarrass anyone'. ${ }^{49}$ Similarly, at a 'smoker' concert organised by the BMSA in 1937, it was agreed unanimously by the student committee that non-medicals would be admitted to the concert but that the distribution of cigarettes would be confined to medical students. ${ }^{50}$ Smoking thus had particular meanings for medical students. Not only was it seen as a peculiarly masculine activity, and in this way, further served to segregate men and women students, but it also helped to cover the smell of formaldehyde and acted as a tool in calming the nerves associated with one's first entrance to the dissecting room.

As well as entry to the dissecting room, Irish student magazines and doctors' memoirs often single out examinations as being an important rite of passage. Deslandes has shown how competitive university examinations were viewed as tests of character and 'could be manipulated symbolically to allow undergraduates to vent competitive spirits; formulate, express and preserve gender identities; and articulate some of the primary concerns of late adolescents on the cusp of manhood. ${ }^{51}$ Examinations were constructed as 'horrific ideals, tests of character, and sacred masculine rituals'. ${ }^{52}$ As Brown has shown for the British medical profession in the nineteenth century, medical practitioners became invested in a particular vision of militarised masculinity. ${ }^{53}$ Similarly, medical examinations were often described in militaristic terms by Irish students. Q.C.G. in 1902 reported of 'hostilities between Examiners and Medicals at Earl's Fort' (a play of words on 'Earlsfort Terrace' in Dublin, where examinations were held), explaining that the 'Medical forces are pretty strong...the preparation of their full war equipment is being rapidly pushed forward, and they 
are expected to be ready to take the field towards the middle of April' ${ }^{54}$ These types of strategies helped to define examinations as a masculine activity, which was increasingly important once women undergraduates began sitting for examinations in the late nineteenth century. ${ }^{55}$ In the Irish context, the achievements of women in examinations were often referred to in the student press in a competitive way. An article in St. Stephen's in 1902 commending the successes of some of its women students in gaining medals in the national examinations, asked 'What a pity it is that "the Boys" don't begin work a short time before the School Examinations! ${ }^{56}$ In this way, women were seen as competitors. Masculinity thus became more important to students at this point as a way of reaffirming their place in the profession in the wake of increasing numbers of women students. Occasionally, such bookworming on the part of the women medical students was called out by their male counterparts. Q.C.C. in 1906, remarked that few lady students attended the student dance that year and asked whether this was on account of them working too hard. ${ }^{57}$ Conscientiousness was also thought to come at a cost to women's physical appearances. In a ballad entitled 'Ragtime Ballade for $1^{\text {st }}$ year medicals' which appeared in T.C.D. magazine in 1917 women medical students 'trotted' to class, 'with big suit-cases, and unwashed faces, lest they should miss the first roll-call' ${ }^{58}$

However, for medical students, examinations were also viewed as important in the transformation of the gyb. One former student at Queen's College Belfast remarked that after first-year summer examinations, students 'were now ready to take our places as the senior students in the dissecting room. We knew that we were no longer freshmen, and that we could afford to look with a kindly eye on those youngsters who had just arrived raw from school, ${ }^{59}$ Examinations also served to civilise rowdy first-year students. Q.C.B. in 1900 remarked that after a visit to Dublin to undertake their examinations the 'boisterous' freshmen now had a 'dejected and subdued appearance'. ${ }^{60}$

Failure to pass examinations had important consequences, meaning that students would not progress but could instead be resigned to what was described as the 'chronic student'. Chronic students were students who took several years to qualify with a medical degree, if they even did qualify, and were a feature of Irish medical schools until at least the 1940s. ${ }^{61}$ These students failed to progress past their first or second year of medical study, were often prone to drinking, and may be viewed as a step down in the hierarchy of medical student masculinities, denied the full privileges of masculinity. Arthur Wynne Foot, in a lecture to students in Dublin in 1873, described the chronic as incurable....an unwholesome and a 9

URL: http://mc.manuscriptcentral.com/thed Email: M.Freeman@ioe.ac.uk, susannahwright@brookes.ac.uk, t.woodin@ioe.ac.uk 
dangerous member of a profession ashamed to own him'. ${ }^{62}$ Chronics were similarly referred to in derogatory terms in both the student press and in doctors' memoirs. A 1923 poem criticised the chronic, 'the hoary veteran' for his lack of knowledge, ('can't find an acid radicle, or tell it from its base') and inability to pass the 'annual stunt' of examinations. ${ }^{63}$ In this way, chronic students were seen as less manly. Doctors' memoirs also condemned chronics for taking advantage of naïve students. J. Johnston Abraham described the chronic as 'a nuisance and a great corrupter of innocence' while Thomas Garry, who studied in Galway and Dublin, explained that they 'lay in wait for new students who were generally unsophisticated and had plenty of money. Like all addicts whether of drink or drugs, they took immense delight in dragging others down to their own level'. ${ }^{64}$ There are evidently class issues at play here: chronic students had the means to repeat their examinations while students of more limited means had more incentive not to engage in drinking and instead focus on more respectable extra-curricular activities, such as sport, which will be discussed later. However, bad behaviour was not unique to the chronic students and prank-playing and student rags remained an important rite of passage well into the twentieth century, and one which also served to segregate men and women students.

\section{Pranks and rags}

Prank-playing was an important initiation rite for medical students internationally. Challenges to authority at universities in the twentieth century, although usually quite benign and ritualised, were, according to Dyhouse, 'both frequent and frequently tolerated as part of the construction of masculinity, part of the 'natural order of things'. ${ }^{65}$ Medical students were usually singled out in the Irish student press for being the perpetrators of such pranks. This extract from Q.C.B. in 1914 describes 'the ideal medical student' in the following way:

....But to him, the very highest form of humour consisted in gathering a large body of fellow students, and going out with them to cause as much trouble and annoyance as possible in places where there was no danger of receiving any damage themselves. He was, in short, an ideal medical student. ${ }^{66}$

Such representations of boisterous male medical students persisted late into the twentieth century. Prank-playing became an accepted part of medical student life for students in their early years of study, and one which women students were excluded from. Women medical students instead, were often characterised as being studious, hard-working, 'aloof' and cold. ${ }^{67}$ Although arguably student pranks are not distinctive to medical students, they nevertheless 
occupy a particular place in accounts of medical student life in student newspapers and doctors' memoirs, and because medical students studied for the longest period, they had something of a 'delayed adolescence' compared to other students. Students from other faculties frequently commented on this. One piece in Q.C.B. in 1900 remarked that 'sober Artsmen sidle past, filled with reverent awe at the bold independence of the medical chrysalis and feeling in comparison with such glory their lives are but nothing, ${ }^{68}$ The lecture theatre was often a setting for displays of bad behaviour and some of this appears to have been tolerated to a large degree by the professors. In 1903, Q.C.G. reported two medical students who had pinned a duster to the tail of one of the professors, which 'elicited roars of laughter, especially from the perpetrators'. ${ }^{69}$ By the 1930s, there were similar reports, with, James Lloyd Turner Graham, a first-year student at the Royal College of Surgeons in Dublin noting in his diary in 1933 that 'The lectures are generally of a rowdy character. The fellows kick up a din if the lecturer says anything funny and also when he does not. ${ }^{70}$ As mentioned above, although prank-playing was, of course, part of student life, regardless of discipline, it held particular meaning in the world of medical students. Additionally, as Deslandes has argued for Oxbridge, contained within 'humorous acts were more serious messages about the abilities of undergraduates to disrupt and unsettle figures of authority and briefly subvert Oxbridge institutional and masculine hierarchies' ${ }^{71}$ Importantly, Irish medical students were rarely disciplined for such acts and professors showed a remarkable degree of tolerance for them. Saying that, such pranks were generally benign in nature, yet enabled students to disrupt the hierarchy, albeit momentarily. In this way, they may be viewed as acts of rebellion, or just one of the stages in the transformation of medical students from boys to men. Notably, women did not partake in these rites of prank-playing, yet were occasionally the target of these activities. In 1912, Q.C.B. remarked on first-year students answering to each other's names out of turn for the roll call and second-year students squeaking 'Here, Doctor' when a female student's name was called. ${ }^{72}$

Pranks took on a more organised format in yearly student rag days which medical students were taking an active part in by the 1920s and which provide an interesting insight into the student-professor dynamic. ${ }^{73}$ Rags owe their roots to the Medieval Feast of Fools, in which novices and choir boys parodied and mocked their superiors. ${ }^{74}$ Students dressed in strange costumes on rag days, often depicting political or celebrity figures of the day and a noisy procession through the city was arranged. In Belfast, 'rags' were held for charity causes but also for famous visitors or new appointees to chairs in the medical faculty. ${ }^{75}$ A photograph of 
Belfast students on 'Students' Day' 1923 depicts a large group in an assortment of costumes, including Charlie Chaplin, black and white minstrels and clowns. To the left of the photograph is a group of three students dressed as surgeons, with a patient on a tray. One of the 'surgeons' is wielding a large blade-like instrument. ${ }^{76}$ Student rags frequently disrupted city life but were excused to an extent by the fact that the proceeds from the day were donated to charity. ${ }^{77}$ Moreover, professors often participated in the initiation rituals as part of these proceedings. For example, in 1923, three new medical professors, C.G. Lowry, W.W.D. Thomson and Andrew Fullerton willingly took part in a special initiation ritual for the rag day in Belfast. Lowry was made ride a donkey bareback down to the centre of the city while Thomson and Fullerton 'were captured between lectures, dressed in their pyjamas, gowns and mortarboards...they rode in a brougham drawn by long ropes manned by students' ${ }^{78}$ The two professors were forced to drink champagne and were anointed with oil over a laurel crown. ${ }^{79}$ This act is revealing - the students were the ones in control of initiation of the professors, in this way turning the trend of student transformation into doctors on its head. The professors willingly gave up their power temporarily, and were anointed into the student body. Doctors and students at Irish hospitals also jointly occasionally organised rags reinforcing the group dynamic. In 1921, the Jervis Street Hospital, Dublin, held a rag to raise money for the hospital with students and doctors alike dressed in costumes. ${ }^{80}$ Medical students often armed themselves with the motifs of their profession, often wielding the masculine instruments of blades and scalpels. Mary Semple, an arts student at UCD in the 1930s recalled that on rag days, six to ten carts with tableaux would parade through the city and that the medical students usually did a 'mock-up of an operating theatre with a recumbent figure and surgeons brandishing fearsome instruments' ${ }^{81}$ Student rags could often take on an element of hooliganism and during the 1930s it appears that bad behaviour escalated. In 1933 during the Trinity College rag, policemen were shelled with eggs after which the 'ragging of the shops commenced'. ${ }^{82}$ Such activities led to the cancellation of the Trinity Rag Day in $1939 .{ }^{83}$

Why were pranks and occasions of rowdiness given so much credence in the student press and subsequently in doctors' memoirs? As Roy Porter has argued for the British context, the 'boisterous, jovial sporting atmosphere of the all-male medical school with its student hijinks and horseplay' consolidated an 'esprit de corps that helped doctors to present some kind of united front'. ${ }^{84}$ Such activities not only helped to bond students together but the subsequent collective memory of shared experiences helped to unite male members of the medical profession. As some Irish doctors' memoirs have suggested, boisterous activities also 
allowed medical students to get any 'rowdyism' out of their system before they went on to become professional men. Moreover, returning to my earlier point about medical studies being viewed as a struggle or time of hardship, such pranks or displays of rowdy behaviour also served to counteract feelings of despondency at the more difficult aspects of medical education. For this reason, it appears that prank-playing and mischief were for the most part excused. In his memoirs, J. Johnston Abraham commented that bad behaviour was 'the result of coming up against pain and suffering and the gruesome side of life at a time when the only way they can react against it is to rush to the other extreme and hilariously ignore it' ${ }^{85}$

Likewise, in his novel The Lion's Whelp, which followed the life of a Belfast-trained doctor, G.M. Irvine excused the medical student for being 'full of animal spirits' because of the fact that he had been 'just freed from the restraint of the family and of school'. ${ }^{86}$ Moreover, he justified such bouts of rowdyism, by claiming that such periodic occurrences were a compensation for days and weeks of 'monotonous book-worming,. ${ }^{87}$ One student at Queen's College Galway stated that the work of the medical student 'is so monotonous and his Exams so tiring, that his levity seems an outlet of Nature for maintaining his mental equilibrium'. ${ }^{88}$ Similarly, one professor in Oliver St. John Gogarty's semi-autobiographical novel Tumbling in the Hay excused the students' 'merriment' on his rounds at the Whitworth Hospital, Dublin that morning and ignored the 'many, very many manifestations of ill-manners and bad breeding' because, in his view these were simply 'indications of ignorance and lack of experience, and I know that these are but transitory manifestations in any man who at heart is sound' ${ }^{89}$ Again, this implies that rowdyism was excused because it was viewed as being part of the transformative process. Displays of bad behaviour may also have been tolerated by professors, perhaps because they themselves had acted similarly in their student days and this was seen as something which one had to engage with in order to complete the transformation from student to fully-fledged practitioner. However, these pranks also served another function: they helped to define who was a member of the group and who was not. Crucially, women did not partake in prank-playing and had a limited role to play in student rags. These activities served to further separate them from the men students.

\section{Rugby}

The main extra-curricular activity which effectually segregated male and female medical students was sport. Sport became an integral aspect of the gentleman's training in the Victorian and Edwardian periods. ${ }^{90}$ Historians have noted the importance of sport, in 
particular rugby, in the culture of medical schools in Britain. ${ }^{91}$ Additionally, Heaman has suggested that at St. Mary's Hospital Medical School in London, sports clubs and games "were intended to foster "social and tender feelings" between students. ${ }^{92}$ Taken at face value, sports teams may be viewed as a means of helping to bond students together; however, the other important aspects of sport for medical students have been neglected. As Messner has convincingly argued in his study of masculinity and sport, sports teams present the image of a "family" with the shared goal of winning which helps to bond its members together. However, this public face masks the reality of intense and constant competition which is part and parcel of athletic participation. ${ }^{93}$ Therefore, like examinations, sport also served to encourage competition and may be viewed as another aspect of homosociality within medical schools. Sport not only helped to promote physical fitness, but encouraged what Tosh has described as 'character-building qualities of courage, self-control, stoical endurance, and the subordination of ego to the team', qualities which resonated with the character formation common in conventional middle-class households where 'pain and emotion were repressed, and individuality curtailed, in the cause of producing a type'. ${ }^{94}$ Moreover, sport also served to further segregate male and female students.

There is ample evidence of the important part that rugby played in the lives of Irish medical students. John A. Murphy has argued that there was a 'virtual interchangeability at the turn of the twentieth century between rugby, college and the medical faculty', noting that out of nineteen out of the twenty students playing rugby for Queen's College Cork in 1876 went on to have medical careers. ${ }^{95}$ Q.C.C. in 1907 referred to the "the "lunaticus footballus"" with his 'ears still filled with the applause of watching hundreds, eyes ever seeing the flying ball, and burning with a mad desire to do for that ---- idiot who plays so beastly foul!"96

Professors at Irish medical schools were active in promoting sport at university level. Although Waddington has argued that the impetus for the founding of sports clubs usually came from medical students themselves, professors played an important role in supporting sport at university level in Ireland. ${ }^{97}$ At Queen's College Cork in 1906, five out of the seven guarantors were professors in the medical faculty while Professor Pearson, the professor of surgery was commended for changing the hour of his Wednesday lecture from four to twelve o'clock to allow the students Wednesday afternoon free for football. ${ }^{98}$ Irish medical schools actively advertised their sports facilities as a means of encouraging prospective students. For example, the prospectus for the Belfast Medical School in 1903 boasted that its playing fields were 'one of the finest grounds in Belfast for this purpose, fully formed and enclosed, and 
situated in close proximity to the College'. ${ }^{99}$ This indicates the type of men that medical schools were trying to attract to their courses; sporty, middle-class men who were robust, healthy and disciplined.

Sport was advocated by professors as being important for promotion of good health and to counteract bad behaviour. As early as 1868, E.D. Mapother, professor of anatomy and physiology at the Royal College of Surgeons remarked on the importance of training 'the physical as well as the mental faculties, which are closely interdependent' in order to combat the threat of contagious diseases to which medical students were often exposed. He argued that every medical school should provide facilities for the playing of sport and suggested that students' spare time should be spent in the ball-court, gymnasium or cricket field, rather than 'smoking at the dissecting room fires, or in the taverns to which want of occupation will tempt them, ${ }^{, 00}$ Students also seemed to have been aware of the importance of exercise to their mental health. In 1879, in a letter to the Medical Board, students at the Adelaide Hospital spoke of how they felt 'very keenly the want of outdoor exercise' due to spending the majority of their time within the bounds of the hospital. ${ }^{101}$ There is therefore, a sense that sport could help to combat stress while also encouraging discipline and hard work. Similarly, Philip Crampton Smyly (1838-1904), former president of the Royal College of Surgeons, illustrated to students how the discipline, self-control and skills learnt through playing rugby could be applied to their studies and careers:

Similar laws and training, similar earnestness and self-control, ensure similar results. The bodily training must be perfect; too much at once or too little is equally futile. It is the same with the mind. You would not have your cup this year had you trained your bodies as some of you try to train your minds for your examinations. Give something of the same training to your hands and minds as you do to your feet and bodies. You will then be successful, and win, not only the hospital challenge cup, but you will be successful men - men of the hand-surgeons. ${ }^{102}$

In this instance, male medical students were encouraged to play rugby because the same skills could be applied to the practice of surgery, which was seen as a fundamentally male domain of practice. There is also a sense that playing sport could help to encourage discipline and camaraderie among the students, qualities which would be useful in their future careers. James Craig encouraged students at the Meath Hospital in 1893 to take part in rugby and 'win renown' by helping to attain the 'much-coveted' Hospitals' Cup again. ${ }^{103}$ The Hospitals' Cup 
was a rugby tournament founded in 1884 with the establishment of the Dublin Hospital Football Union which was composed of representative doctors from each of the Dublin hospitals. ${ }^{104}$ The competition was an important fixture in the medical student's calendar with matches never failing 'to excite a considerable amount of interest in student circles'. ${ }^{105}$ In London, similar competitions existed between the rugby teams of the hospitals there. ${ }^{106}$ These events also acted as valuable fundraising events for hospital charities and 'worthy causes'. 107 Students were dedicated to these competitions and success in sport was believed to reflect positively on the reputation of the medical school, shedding 'lustre on the College and on the faculty'. ${ }^{108}$ Intense rivalries developed between different teams, particularly, it seems, between the "Mater Boys" and "Vincent's". ${ }^{109}$ Such rivalries would certainly have helped to cement students' sense of collegiality. Success in the Hospital Cup competition was also positively reinforced by medical staff. In 1921, the Honorary Secretary of the Medical Board of the Meath Hospital was directed to organise a picnic in connection with the Football Club as an acknowledgement of their success in winning the Hospitals Cup. ${ }^{110}$

Occasionally there were tensions between sport and academic life. In 1898, the BMSA, in cooperation with the college sports clubs, approached the College Council to request a Wednesday half-holiday for the purpose of allowing students to play sport. ${ }^{111}$ In 1908 the medical faculty at Trinity College was petitioned to change the 'Half' examinations to April or May and for afternoon lectures to be re-arranged to the morning so that medical students could partake in cricket practice. ${ }^{112}$ Professors were not always sympathetic to this interest in sport. In 1908, the Professor of Anatomy and Physiology at University College Galway, J.P. Pye, wrote a letter to the College Council, in which he claimed that the working of his classes that session had been so unsatisfactory, that he felt it his duty to write such a report. He complained about a lack of attendance at lectures and 'a change in tone' which he attributed directly to:

.....the encouragement given by the College to Athletics. I do not think the students who come here are in a position to indulge in the luxury of athletics - to the extent or at least of competitions in Belfast or Dublin - but this is not all. I cannot help noticing certain concomitants of athletics which are an unmitigated evil, as well as a considerable nuisance to other people. It is the duty of the College to take note of such things. ${ }^{113}$ 
For the month of February, he noted six occasions when he had been present to give lectures on Experimental Physiology and the entire class had been absent. ${ }^{114}$

Nevertheless, in spite of these tensions, rugby remained popular amongst the medical students. The sport was often described by students in militaristic terms, perhaps in an attempt to further promote an image of the doctor as heroic. In 1904 in one Irish student magazine it was depicted as 'jerseyed combat' while another piece, eighteen years later, described how students in Galway carried a 'wounded comrade' with a 'bloody gash received on the rugger field' to the anatomy room where he was laid 'on a grimy table beside the mutilated remains of what was once a man'. ${ }^{115}$ The secretary's report for University College Cork's rugby club in 1909-10 described the game in militaristic terms 'I can assure you that the red and black jerseyed brigade will be a force in Munster football, add lustre to College football fame and gladden the heart of many a veteran who on many a land fought and gathered the laurels of victory for the grand "old skull and cross bones",116

Rugby became central to an ideology of manliness in sport, as it promoted unselfishness, fearlessness and self-control. ${ }^{117}$ These were qualities which were also expected of doctors in the period. There was also an important class element to the playing of rugby. Murphy has suggested that at Queen's College Cork, rugby 'had everything to do with hereditary professional position, exclusive education, leafy suburbs and desirable residences'.118 Students were encouraged to play rugby, because it fitted in with ideals and notions of respectability which were particularly important to the Irish medical profession. In 1914, a fictional letter from 'A Proud Parent to his son, a medical gyb' appeared in The Quarryman, stating:

We all derived the hugest amusement from your account of the football matches. College men are famous the world over as footballers, and now that you are a fullblown member of their celebrated Rugby Club, you will naturally take a special pride in their achievements. The subscription (one guinea) was a bit thumping, but this only proves the select nature of the club, so don't worry about it. When a select club admits you to membership, you must not groan if such a club should make you pay through the nose for the privilege. ${ }^{119}$

Although satirical in nature, the piece emphasises the exclusive nature of the rugby teams of Irish medical schools and the fact that those playing it were coming from a certain class. Indeed, rugby also had important cultural and class connotations: it was primarily viewed as 
an English sport, and one with associations with the professional classes. Although this period witnessed the popularisation of Gaelic sports, which McDevitt has argued, were created as a means of refuting British influence, there is little evidence to suggest that medical students took a great interest in these. ${ }^{120}$ Even following the creation of the Irish Free State in 1922, rugby continued to be associated with medical students. This may have been for a few reasons: firstly, rugby was more successful at embodying the characteristics expected of the Irish medical profession in the period and was a more bloody game than the Gaelic sports where the 'intellectual aspects of the game were paramount" ${ }^{\text {"21}}$; secondly, its class associations, and finally, the fact that Irish practitioners were reliant on the British market for posts may have meant that they were less inclined to reject British games. ${ }^{122}$ Nevertheless, not all medical students readily conformed to the stereotype of the sporting male student. The writer of a fictional account in 1913 mentioned 'a prolonged spell of hospital' following his first practice game. ${ }^{123}$ Noel Browne, who studied at Trinity College in Dublin in the 1930s, reluctantly played rugby 'mainly for the companionship'. He also hesitantly joined the boxing team but resigned from the 'silly and dangerous sport' after being filled with remorse after knocking another boxer unconscious. ${ }^{124}$

Involvement in sport occasionally had positive social and career consequences for budding Irish doctors. ${ }^{125}$ Smith, a medical student in The Lion's Whelp, gained popularity at Queen's for 'being a jolly fellow and a good football player'. ${ }^{126}$ Bethel Solomons was captain of the Trinity College rugby team in the 1900 s and went on to gain ten international caps for the Irish national team. He noted that being a good rugby player could affect one's choice of hospital and future career, remarking that 'scouting parties of housemen and senior students would visit the dissecting rooms to try and enlist good Rugby players' to join particular hospitals. ${ }^{, 127}$ Following qualification, Solomons' sporting life influenced his career path. Because he was captain of the university football club, it was expected that he would remain in Dublin. He was also offered a commission in the Royal Army Medical Corps, 'like most other international rugby players at that time'. ${ }^{128}$ Again, this suggests that the Irish medical profession was trying to encourage well-rounded, healthy men.

Women medical students were very much excluded from this male sporting world. 'Lady medicals' had the option of joining hockey and tennis clubs if they wished to take part in sporting activities, but there is little sense from the contemporary sources that they were involved to a great degree in these in the period in question. In fact, one critical editorial in T.C.D. in 1924 suggested that the 'corporate spirit is not inculcated in girls as it is in boys' 
and that 'esprit de corps is lacking from their vocabulary'. ${ }^{129}$ In response, a female student argued that women students had fewer facilities available to them for extra-curricular activities than the men students while also pointing out that the women's residence was several miles away from the College, unlike the men's on-campus accommodation. Furthermore she remarked that female students were 'firmly excluded from the real life of College' but that when 'any chance is given to them they only too willingly rise to meet the occasion'. ${ }^{130}$ Ironically, it was often the female medical students who fundraised for improved sports facilities for the men students. In 1907, a group of Belfast medical students organised a fete to raise money for a new athletic field, however, the president of the Students' Representative Council complained that the female students were the only ones showing a 'proper amount of zeal by organising a stall'. ${ }^{131}$

\section{Conclusion}

The article has illustrated how various aspects of Irish medical education and student culture were couched in a highly masculine rhetoric in the student press and subsequently in recollections in doctors' memoirs. Although women were treated in an egalitarian manner with regard to their educational experiences at Irish institutions, the increased emphasis on masculine rites of passage suggests underlying fears about the introduction of women to the medical profession. As Brown has suggested, in the nineteenth century, medical invocations of military masculinity in Britain might be seen as 'an attempt to construct medicine as an exclusively masculine domain to divest it of its domestic associations and to harvest forms of symbolic capital that were significantly less accessible to women'. ${ }^{132}$ In the same way, it could be argued that with increasing numbers of women medical students entering Irish institutions from the 1890s onwards, sport and activities of a boisterous nature came to play a more prominent role as medical practitioners, amidst fears of an already overcrowded medical marketplace, attempted to cultivate a masculine image of the doctor. Furthermore, male medical students were increasingly encouraged to partake in sport in order to be betterrounded, while doctors' memoirs and autobiographies highlighted the playing of sport and pranks, thus perpetuating a collective memory which separated them from women doctors.

Educational activities such as anatomy dissections and examinations were also described in highly masculine terms while social activities such as pranks, rags and sport, further served to segregate women medical students from the men. All of these aspects display the hallmarks of homosociality: competition, emotional detachment and sexual objectification and 
ultimately characterised Irish medicine as a largely male preserve. Segregation also played out subsequently in the careers of women doctors. Of a sample of women doctors who matriculated at Irish universities between 1885 and 1922, only $16 \%$ were working in hospital appointments five years after graduation, with $70 \%$ working in general practice. ${ }^{133}$ Although the first generation of Irish women doctors had broken new ground in entering medical schools, they found themselves subject to the confines of hegemonic masculinity in their student lives and subsequent careers.

\footnotetext{
Notes

${ }^{1}$ John Harley Warner and James M. Edmondson, through the use of dissecting-room photographs, have effectively explored this important facet of medical student life. See: Dissection: photographs of a rite of passage in American medicine 1880-1930, (Blast Books, 2009).

${ }^{2}$ Thomas Neville Bonner, Becoming a physician: medical education in Britain, France, Germany and the United States, 1750-1945, (Oxford University Press, 1995), 7.

${ }^{3}$ Keir Waddington, 'Mayhem and medical students: image, conduct, and control in the Victorian and Edwardian London Teaching Hospital', Social History of Medicine, 15:1, (2002), 46.

${ }^{4}$ See for example: Anne Crowther and Marguerite Dupree, Medical lives in the age of surgical revolution, (Cambridge University Press, 2007) and Florent Palluault, 'Medical students in England and France 1815-58: a comparative study', (Unpublished $\mathrm{PhD}$ thesis, University of Oxford, 2003), Laura Kelly, 'Migration and medical education: Irish medical students at the University of Glasgow, 1859-1900', Irish Economic and Social History, 39, (2012).

${ }^{5}$ Crowther and Dupree, Medical lives in the age of surgical revolution, (Cambridge University Press, 2007), 945.

${ }^{6}$ Recent important studies of medical education include: S.C. Lawrence, Charitable knowledge: hospital pupils and practitioners in eighteenth-century London, (Cambridge University Press, 1986); Lisa Rosner, Medical education in the age of enlightenment: Edinburgh students and apprentices, 1760-1826, (Edinburgh University Press, 1991), Jonathan Reinarz, Health care in Birmingham: the Birmingham teaching hospitals, 1779-1939, (Woodbridge: Boydell Press, 2009), Lisa Rosner, 'Student culture at the turn of the nineteenth century', Caduceus, 10:2, (1994), 65-86, Colin Jones, 'Montpellier medical students and the medicalisation of $18^{\text {th }}$ century France' in: Roy Porter and Andrew Wear (eds.), Problems and methods in the history of medicine, (London: Croom Helm, 1987), 57-80, Keir Waddington, Medical Education at St. Bartholomew's Hospital, 1123-1995, (Woodbridge: Boydell Press, 2003), Mark. W. Weatherall, Gentlemen, scientists and doctors: Medicine at Cambridge, 1800-1940, (Woodbridge: The Boydell Press, 2000), E.A. Heaman, St. Mary's: the history of a London teaching hospital, (Montreal: McGill-Queen's Press, 2003).
} 


\footnotetext{
${ }^{7}$ Paul R. Deslandes, Oxbridge Men: British Masculinity and the Undergraduate Experience, 1850-1920,
} (Indiana University Press, 2005) and Heather Ellis, 'Foppish Masculinity, Generational Identity and the University Authorities in Eighteenth-Century Oxbridge', Cultural and Social History, 11:3, (2014), 367-384.

${ }^{8}$ See for example: on Queen's College Cork: Denis J. O'Sullivan, The Cork school of medicine: a history, (Cork: UCC Medical Alumni Association, University College Cork, 2007) and Ronan O'Rahilly, A history of the Cork medical school, 1849-1949, (Cork: Cork University press, 1949); Queen's College Galway: James Murray, Galway: a medico-social history, (Galway: Kenny's bookshop and art gallery, 1994); Queen's College Belfast: Peter Froggatt, 'The distinctiveness of Belfast medicine and its medical school', Ulster medical journal, 54:2, (October, 1985), 89-108; Royal College of Surgeons: J.B. Lyons, The irresistible rise of the RCSI, (Dublin: Royal College of Surgeons, 1984), Eoin O'Brien, The Royal College of Surgeons in Ireland: 17841984, (Dublin: Eason, 1984); J.D.H. Widdess, The Royal College of Surgeons in Ireland and its medical school, (Edinburgh: E \& S Livingstone, 1967), Charles A. Cameron, History of the Royal College of Surgeons in Ireland and of the Irish schools of medicine, including numerous biographical sketches, also a medical bibliography, (Dublin: Fannin, 1886); Royal College of Physicians: J.D.H. Widdess, $A$ history of the Royal College of Physicians of Ireland, 1654-1963, (Edinburgh: E \& S Livingstone, 1964); Trinity College Dublin: TPC Kirkpatrick, History of the medical teaching in Trinity College Dublin and of the School of Physic in Ireland, (Dublin: Hanna and Neale, 1912); the Catholic University: F.O.C. Meenan, Cecilia Street: the Catholic University School of Medicine 1855-1931, (Dublin: Gill and Macmillan, 1987); Ronan O'Rahilly, Benjamin Alcock: the first professor of anatomy and physiology in Queen's College Cork, (Cork: Cork University Press, 1948).

${ }^{9}$ In recent years, historians such as Warner and Brown have paid more attention to the different ways that doctors constructed, 'performed' and articulated their professional identity. See for instance, important work by John Harley Warner, The therapeutic perspective: medical practice, knowledge and identity in America, 18201885, (Princeton University Press, 1997) and Against the spirit of system: the French impulse in nineteenthcentury American Medicine, (John Hopkins Press, 1998); and Michael Brown Performing Medicine: Medical culture and identity in provincial England, c.1760-1850, (Manchester University Press, 2011) and 'Like a devoted army: Medicine, heroic masculinity and the military paradigm in Victorian Britain', Journal of British Studies, 49:3, (2010), 592-622. Ludmilla Jordanova has illustrated how physicians in the late eighteenth and early nineteenth century promoted a collective image of themselves as reliable, dependable and 'politely manly' through the medium of portraiture (Ludmilla Jordanova, 'Medical men 1780-1820', in Joanna Woodall (ed.), Portraiture: facing the subject, (Manchester University Press, 1997), p.101-118) while more recently, Mary Hunter and Keren Rosa Hammerschlag's imaginative work has shown how portraiture reflected status and medical masculinities in the nineteenth century. (See: Mary Hunter, ' Intern, Orderly, Artist, Corpse: Emerging Masculinities in Henri Gervex's Autopsy at Hôtel-Dieu', Oxford Art Journal, 38:3, (2015), 405-426 and Keren Rosa Hammerschlag, 'The Gentleman Artist-Surgeon in Late Victorian Group Portraiture', Visual Culture in Britain, 14:2, (2013), 154-178.)

${ }^{10}$ See: Laura Kelly, "Fascinating Scalpel-wielders and Fair Dissectors": Women's Experience of Irish Medical Education, c. 1880s-1920s, Medical History, 54:4, (2010), 495-516. Kelly, 'Fascinating scalpel-wielders'.

${ }^{11}$ Kelly, 'Fascinating scalpel-wielders'. 
${ }^{12}$ Carol Dyhouse, Students: a gendered history, (Oxford: Routledge, 2005), 153.

${ }^{13}$ Greta Jones, "Strike out Boldly for the Prizes that are Available to You": Medical Emigration from Ireland 1860-1905, Medical History, 54:1, (2010), 55-74.

${ }^{14}$ See: Elaine Sisson, Pearse's patriots: St. Enda's and the cult of boyhood, (Cork University Press, 2004),16-17 and Joseph Valente, The Myth of Manliness in Irish National Culture, 1880-1922, (University of Illinois Press, 2011).

${ }^{15}$ George L. Mosse, The Image of Man: the creation of modern masculinity, (Oxford University Press, 1996), 109-110.

${ }^{16}$ R.W. Connell, Masculinities, $2^{\text {nd }}$ edition, (Berkeley: University of California Press, 2005), 77.

${ }^{17}$ R.W. Connell, Gender and power: society, the person, and sexual politics, (Cambridge: Polity Press, 1987), 185-6.

${ }^{18}$ John Tosh, 'What Should Historians Do with Masculinity? Reflections on Nineteenth-Century Britain', History Workshop, 38 (1994), 184.

${ }^{19}$ Tosh, 187.

${ }^{20}$ Sharon R. Bird, 'Welcome to the men's club: homosociality and the maintenance of hegemonic masculinity', Gender \& Society, 10:2, (1996), 121-2.

${ }^{21}$ Paul R. Deslandes, 'Competitive Examinations and the Culture of Masculinity in Oxbridge Undergraduate Life, 1850-1920', History of Education Quarterly, 42:4, (2002), 547.

${ }^{22}$ Heather Ellis, 'Boys, semi-men and bearded scholars': Maturity and Manliness in Early Nineteenth-Century Oxford in S. Brady and J. H. Arnold (eds.), What is Masculinity? Historical Dynamics from Antiquity to the Contemporary World (Palgrave Macmillan, 2011), 267.

${ }^{23}$ For instance, in H. A. Hinkson Student life in Trinity College, Dublin, (Dublin: J. Charles \& Son, 1892), university life is described as 'a time when one stands on the very edge of life, eager for a plunge into life's joyous waters, when one has assumed the toga of one's manhood, and is yet a boy in heart'. Hinkson, 5 . 24 'As others see us', 4. and 'Advice to freshmen', T.C.D., 44:763, October 28, 1937, 8. 'Pre-reg notes', The University Annual: University College Galway, 5:4, 1927-28, 55.

25 'First impressions', 13.

26 'The medicus', Q.C.C., 3:1, January 1907,5.

27 'The Schools: the medical school, Q.C.B., 5:1, November 26, 1903, 12.

${ }^{28}$ Rawdon Macnamara, 'An address, introductory to the session 1884-1885, delivered in the theatre of the Meath Hospital and County of Dublin Infirmary', (Dublin: J. Atkinson \& Co., 1884), 10.

${ }^{29}$ Rawdon Macnamara, 'Abstract of the introductory addresses delivered at the Dublin Hospitals and Medical Schools, Session 1881-82', Lancet, November 26, 1881, 912.

30 'The last lecture', Q.C.B., 13:8, June 1912, 13.

31 'As others see us', 4.

32 'First impressions', St. Stephen's, 2:9, December 1905, 195.

33 'Belfast Medical Students' Association', BMJ, February 3, 1912, 270.

${ }^{34}$ Warner and Edmonson, through the effective use of a range of photographs from American medical schools, have underlined the importance of dissection to professional identity. See: Dissection: photographs of a rite of passage in American medicine, 1880-1930, (New York: Blast Books, 2009). 
${ }^{35}$ One poem published in 1917 remarked on the 'nervous eye' of the student upon entering the dissecting room.

'The student's progress', R.C.S.I. Students' Quarterly, 1:1, February 1917, 5.

36 'First impressions', The National Student, 2:6, December 1911, 12.

37 'First impressions', 13.

38 'First impressions', 12.

39 'Medical notes', Galway University College Magazine, 2:9, 1922-23, 21.

40 'First impressions', 12.

41 'College Notes', R.C.S.I. Students' quarterly, 1:3 November 1917, 44

${ }^{42}$ One student remarked in 1911 that 'the consumption of tobacco is certainly enormous, and the bright gas jets dependent from on high give to the whole an appearance of comfort that a sudden entry without cannot but help to appreciate'. 'First impressions', 12.

${ }^{43}$ Robert A. Nye, 'Medicine and Science as Masculine "Fields of Honor"', Osiris, Vol. 12, (1997), 76. Keren Hammerschlag, in her discussion of a late nineteenth-century portrait by Solomon Joseph Solomon of the surgeon Ernest Abraham Hart, who is depicted smoking a cigarette, suggests that the depiction of Hart with a cigarette 'may be understood as an attempt at forging an alternative yet still acceptable late-Victorian masculine identity'. (Keren Rosa Hammerschlag, 'The Gentleman Artist-Surgeon in Late Victorian Group Portraiture', Visual Culture in Britain, Volume 14, Issue 2, (2013), 170-1.)

${ }^{44}$ Walter Rivington, The Medical Profession of the United Kingdom, (Dublin: Fannin \& Co., 1888), 700. In 1909, for example, University College Galway provided students with a refurbished combined smoking and reading room. UCG: A College Annual, 1:1 (February 1909), 24

45 "News from "The Schools"', T.C.D., 6:103, November 10, 1900, 129-130.

${ }^{46}$ J. Johnston Abraham, Surgeon's journey: the autobiography of J. Johnston Abraham, (London: William Heinemann Ltd., 1957), 46.

${ }^{47}$ Thomas Hennessy, My life as a surgeon: an autobiography, (Dublin: A\&A Farmar, 2011), 69.

${ }^{48}$ Matthew Hilton, Smoking in British popular culture 1800-2000, (Manchester University Press, 2000), 130.

49 'My impressions of the Dissecting Lab by a Man of Law', T.C.D, 304:587, November 24, 1927, 50.

50 'Committee meeting 21 Jan, 1937’, BMSA Minute Book 1932-48, Royal Victoria Hospital Archives.

${ }^{51}$ Deslandes, 'Competitive Examinations', 556.

${ }^{52}$ Ibid, 577-8.

${ }^{53}$ Michael Brown, “'Like a devoted army": Medicine, heroic masculinity, and the military paradigm in Victorian Britain', Journal of British Studies, 49:3 (July 2010), 592-622.

54 'War threatened in the extremely near east', Q.C.G., 2:2, February 1904, 52.

${ }^{55}$ Deslandes, 'Competitive examinations', 577-8.

56 'News from 'The School', St. Stephen's: a record of university life, 1:8, November 1902, 172. Another piece in Q.C.B. remarked that the lady medical was 'more diligent, assiduous' than the male student. ('Winsome woman', 7.)

57 'Aphroditiana', Q.C.C., 2:3, March 23, 1906, 58.

58 'Ragtime Ballade for $1^{\text {st }}$ year medicals, entitled Dixie', T.C.D: a college miscellany, 23:395, February 7, 1917, 68.

${ }^{59}$ R.W.M. Strain, Les neiges d'antan, (R. Strain, 1982), 9. 
60 'The Schools: The medical school', Q.C.B., 2:1, November 20, 1900, 9.

${ }^{61}$ From the 1940s, Irish universities took measures to eliminate the problem of chronic medical students. For instance, at University College Cork, from 1946, students were given two years to pass each of the first three examinations in Medicine. (Alfred O'Rahilly, 'Limiting the number of medical students', Cork University Record No.7, Summer 1946, 24.)

${ }^{62}$ Arthur Wynne Foot, 'An introductory address delivered at the Ledwich School of Medicine, November $1^{\text {st }}$, 1873', (Dublin: John Falconer, 1873), 17.

63 'The same old second-medical', Fravlio-Queens, June 1923, 6.

${ }^{64}$ Abraham,.46 and Thomas Garry, African Doctor, (London: John Gifford Ltd., 1939), 15.

${ }^{65}$ Dyhouse, 177

${ }^{66}$ A Medical Biography, Q.C.B., 16:4, February 1914, 10.

67 'The impressions of one “Abdullah”, first year student of medicine', The National Student, 3:2, May 1913, 43 and 'To a surgeon's girl', RCSI Students' Quarterly, 1:1, February 1917, 12.

68 'As others see us', 4.

69 'Medicine', Q.C.G., 1:2, February 1903, 42.

${ }^{70}$ James Lloyd Turner Graham diary, December 7, 1933. RCPI Heritage Centre.

${ }^{71}$ Deslandes,.92.

72 'The Last Lecture', Q.C.B., 13:8, June 1912, 13.

${ }^{73}$ For more on rags see Dyhouse, 186-203.

${ }^{74}$ John R. Gillis, Youth and history: tradition and change in European Age Relations, 1770-present, (New York: Academic Press, 1974), 25-26.

${ }^{75}$ Denis Biggart, John Henry Biggart: Pathologist, Professor and Dean of Medical Faculty, Queen's University, Belfast, (Belfast: Ulster Historical Association, 2012), 32.

${ }^{76}$ Photograph of Students' Day at QUB, April 20, 1923. [MUN/MED/25/22, TCD Manuscripts.]

${ }^{77}$ T.F. O’Higgins, A double life, (Dublin: Town House, 1996), 52-53.

${ }^{78}$ Biggart, 32.

${ }^{79}$ Ian Fraser, 'The first three professors of surgery', Ulster Medical Journal, 1976, 45:1, 39.

80 'Ragging for Charity' video at http://www.britishpathe.com/video/ragging-for-charity, accessed 08/04/13.

${ }^{81}$ Mary Semple, 'Going hatching', in: Anne Macdona (ed.), From Newman to New Woman: UCD Women remember, (Dublin: New Island, 2001), 13.

82 James Lloyd Turner Graham diary, June 12, 1933.

83 'Editorial', T.C.D, 46:813, June 6, 1940, 181.

${ }^{84}$ Roy Porter, The Greatest Benefit to Mankind, (London: Harper Collins, 1997), 356.

${ }^{85}$ Abraham, 44.

${ }^{86}$ G.M. Irvine, The lion's whelp, (London: Simpkin, Marshall, Hamilton, Kent \& Co. Ltd, 1910), 21.

${ }^{87}$ Irvine, 20.

88 'Medicine', Q.C.G., 5:2, February 1907, 50.

${ }^{89}$ Gogarty, Tumbling in the hay, 225-8. 
${ }^{90}$ See J.A. Mangan, Athleticism in the Victorian and Edwardian Public School, (London: Frank Cass

Publishers, 2000) and John Nauright and Timothy J.L. Chandler (eds.), Making men: rugby and masculine identity, (London: Routledge, 1999).

${ }^{91}$ Dyhouse, 152. Garner, 84.

${ }^{92}$ Heaman, 85.

${ }^{93}$ Michael A. Messner, 'Like Family: Power, intimacy and sexuality in male athletes' friendships', in: Peter M.

Nardi (ed.), Men's Friendships, (Newbury Park: SAGE, 1992), 219.

${ }^{94}$ Tosh, 188-189.

${ }^{95}$ John A Murphy, Where Finbarr played: a concise illustrated history of sport in University College Cork, 1911-2011, (Cork: UCC Press, 2011), 89.

96 'The Medicus', 6.

${ }^{97}$ Waddington, 251.

${ }^{98}$ Report read at opening general meeting for the season 1906-07, Rugby Football Club Minutes QCC 19051912 [UC/MB/CS/RF/1], UCC University Archives.

${ }^{99}$ Guide to the Belfast Medical School for session 1903-4, (Belfast: A. Mayne and Boyd, 1903),24.

${ }^{100}$ E.D. Mapother, The medical profession and its educational and licensing bodies, (Dublin: Fannin \& Co., 1868), 117.

${ }^{101}$ Letter to the Medical Board dated $1^{\text {st }}$ of July 1879, Adelaide Hospital Medical Board Minute Book, 17 September 1875-8 May 1880, IE TCD MS 11270/2/3/3/2, TCD Manuscripts.

${ }^{102}$ Philip Crampton Smyly, 'Is it true? An address delivered in the theatre of the Meath Hospital and Co. Dublin Infirmary on Monday, October 3, 1890', (Dublin: John Falconer, 1890), 4.

${ }^{103}$ James Craig, 'Introductory address delivered at the opening of the session of 1893-4 in the theatre of the Meath Hospital', (Dublin: John Falconer, 1893), 7.

${ }^{104}$ Dublin Hospital Football Union Minute Book, 1884-1901, BMS/2/3, RCPI Heritage Centre.

105 'News from the school', St. Stephen's, 1:11, March 1903, 244.

${ }^{106}$ Waddington, 253.

${ }^{107}$ Roberta Park, 'Mended or Ended?': Football Injuries and the British and American Medical Press, 1870-1910', International Journal of the History of Sport, 18:2, (2001), 118.

108 'Medical notes', Galway University College Magazine, 3:1, 1924-25, 85-86.

109 'Notes from the medical school', St. Stephen's, 2:2, February 1904, 33. The Mater and St. Vincent's were two Dublin hospitals.

110 'Meeting of the Medical Board June 23 ${ }^{\text {rd }} 1921$ ', Minute Book, Medical Board of Meath Hospital, 1899-1937, National Archives of Ireland.

${ }^{111}$ Secretaries' Report of year 1898-9, BMSA Minute Book, November 1898 - November 1907, QUB Special Collections.

112 'College Clubs: Cricket: the increasing demands of the professional schools', T.C.D., 14:241, May 13, 1908, 73.

${ }^{113}$ Special report of the Professor of Anatomy and Physiology, March 10, 1908. BU/B/274, NUI Galway Special Collections.

${ }^{114}$ Ibid. 
115 'Notes from the Medical School', St. Stephen's, 2:2, February 1904, 33 and 'Medical notes', Galway University College Magazine, 2:9, 1922-1923, 22.

${ }^{116}$ Secretary's report, 1909-10, QCC Rugby Club Minutes [UC/MB/CS/RF/1], UCC University Archives.

117 J.A. Mangan, The Games Ethic and Imperialism: Aspects of the Differences of an Ideal, (London, 1986), 23.

${ }^{118}$ Murphy, 89.

119 'Letter from a Proud Parent to his son, a Medical Gyb', The Quarryman, 1:4, March 1914, 87.

${ }^{120}$ Patrick F. McDevitt, 'Muscular Catholicism: nationalism, masculinity and Gaelic team sports, 1884-1916', Gender \& History, 9:2, (August 1997), 262-284.

${ }^{121}$ McDevitt, 278.

${ }^{122} \mathrm{McDevitt}$ has suggested that gaelic sports and the opposition of British games marked the first step towards freedom from British control. (McDevitt, 278).

123 'The impressions of one "Abdullah"', 43.

${ }^{124}$ Noel Browne, Against the tide, (Dublin: Gill and Macmillan, 1986), 61.

${ }^{125}$ Peterson has suggested that for the London medical schools in the mid-nineteenth century 'more than one medical student's activities and prowess in the athletic realm brought him recognition as a sportsman and introductions that benefited his professional career'. M. Jeanne Peterson, The medical profession in midVictorian London, (Berkeley: University of California Press, 1978), 62.

${ }^{126}$ Irvine, 20.

${ }^{127}$ Bethel Solomons, One Doctor in His Time, (London: Christopher Johnson, 1956), 41.

${ }^{128}$ Bethel Solomons, 'Medical memories', Irish Times, July 7, 1952, 6.

129 'Editorial', T.C.D, 29:507 May 24, 1923, 158.

${ }^{130}$ Correspondence, T.C.D., 29: 508, May 31, 1923, 176.

131 'Fete news: medical students' stall', Q.C.B. 8:4, February 1907, 14.

${ }^{132}$ Brown, 4.

${ }^{133}$ Laura Kelly, Irish women in medicine, c.1880s-1920s: origins, education and careers, (Manchester University Press, 2012), 112. 